\title{
PENGARUH PENDIDIKAN GIZI MELALUI KOMIK GIZI SEIMBANG TERHADAP PENGETAHUAN DAN SIKAP PADA SISWA SDN BENDUNGAN DI SEMARANG
}

\author{
Marisa, Nuryanto*) \\ Program Studi Ilmu Gizi Fakultas Kedokteran Universitas Diponegoro \\ Jl.Dr.Sutomo No.18, Semarang, Telp (024) 8453708, Email : gizifk@undip.ac.id
}

\begin{abstract}
Background: Nutritional problems are more common in children of primary school age is due to a lack of knowledge of nutrition. The recent nutritional guidelines that exist in Indonesia, called "Tumpeng Gizi Seimbang" have not properly socialized. Comic becomes one of the very popular media that children who have now been widely used as educational media. Nutrition education with the medium of comics is expected to improve the knowledge and attitude about balance nutrition especially for children.

Methods: This research was a quasi-experimental pre-post test two group design on 66 student of Bendungan Elementary School in Semarang grades $4^{\text {th }}$ and $5^{\text {th }}$. The subjects were divided into 2 groups: group 1 were given only comics and group 2 were given comics and mentoring once a week for a month. Knowledge and attitude about balance nutrition obtained from interviews used a structured questionnaire. Effect of nutrition education on knowledge and attituds in both groups were tested used paired t-test, Wilcoxon and Mann Whitney.

Results: The increase of median balance nutrition knowledge in group 1 before intervention was 56\% to $72 \%$, whereas in group 2 the average knowledge was $61.82 \pm 11.09 \%$ to $80,85 \pm 10.43 \%$. The increase of the median balance nutrition attitude in group 1 before intervention was $64 \%$ to $88 \%$, while the increase of median in attitude in group 2 was $60 \%$ to $84 \%$. There was a difference in the improvement of nutritional knowledge among groups 1 and 2 (p $<0.05)$, but there was no difference in improvement of nutritional attitude between groups 1 and $2(p>0.05)$.

Conclusions: Nutrition education with balance nutrition comic improve knowledge and attitude about balanced nutrition in both groups. There was a differences in the improvement of knowledge between groups 1 and 2. There was no difference in the improvement of attitudes between groups 1 and 2.
\end{abstract}

Keywords: Knowledge; Attitude; Balanced Nutrition Comics; Elementary Students

\section{ABSTRAK}

Latar Belakang : Permasalahan gizi yang banyak terjadi pada anak usia sekolah dasar salah satunya disebabkan kurangnya pengetahuan gizi. Pedoman gizi terbaru yang ada di Indonesia yakni Tumpeng Gizi seimbang juga belum dapat tersosialisasi dengan baik. Komik menjadi salah satu media yang sangat digemari anak - anak yang kini telah banyak dimanfaatkan sebagai media pendidikan. Pemberian pendidikan gizi melalui media komik diharapkan dapat meningkatkan pengetahuan dan sikap tentang gizi seimbang khususnya bagi anak - anak.

Metode : Penelitian ini berjenis quasi experimental dengan pre-post test two group design pada anak SDN Bendungan kota Semarang kelas IV dan V sebanyak 66 anak. Subyek dibagi menjadi 2 kelompok yaitu kelompok perlakuan 1 yang hanya diberikan komik dan kelompok perlakuan 2 yang diberikan komik dan pendampingan seminggu sekali selama satu bulan. Data pengetahuan dan sikap tentang gizi seimbang diperoleh dari wawancara menggunakan kuesioner terstruktur. Pengaruh pendidikan gizi terhadap pengetahuan dan sikap pada kedua kelompok diuji menggunakan uji paired t-test, Wilcoxon dan Mann Whitney.

Hasil : Peningkatan median pengetahuan gizi seimbang pada kelompok perlakuan 1 dari sebelum nya sebesar 56\% menjadi $72 \%$, sedangkan pada kelompok perlakuan 2 rerata pengetahuan sebelum sebesar 61,82 $\pm 11,09 \%$ menjadi $80,85 \pm 10,43 \%$. Peningkatan median sikap gizi seimbang pada kelompok perlakuan 1 dari sebelumnya sebesar $64 \%$ menjadi $88 \%$, sedangkan peningkatan median sikap pada kelompok perlakuan 2 dari sebelum nya sebesar $60 \%$ menjadi 84\%. Terdapat perbedaan pada peningkatan pengetahuan gizi antara kelompok perlakuan 1 dan $2(p<0,05)$, namun tidak terdapat perbedaan peningkatan sikap gizi antara kelompok perlakuan 1 dan $2(p>0,05)$.

Kesimpulan : Pendidikan gizi melalui komik gizi seimbang meningkatkan pengetahuan dan sikap tentang gizi seimbang pada kedua kelompok. Terdapat perbedaan pada peningkatan pengetahuan antara kelompok perlakuan 1 dan 2. Tidak ada perbedaan pada peningkatan sikap antara kelompok 1 dan 2.

Kata Kunci : Pengetahuan; Sikap; Komik Gizi Seimbang; Siswa SD

\section{PENDAHULUAN}

Anak usia sekolah dasar (7 - 12 tahun) adalah kelompok usia yang masih mengalami tumbuh kembang dan memerlukan kebutuhan zat gizi yang cukup dan sesuai untuk menunjang tumbuh kembang mereka, namun pada masa ini anak - anak memiliki kebiasaan makan yang kurang baik sehingga banyak kebutuhan zat gizi yang tidak dapat terpenuhi dengan optimal. Asupan zat gizi yang tidak tepat pada masa kanak - kanak dapat

\footnotetext{
${ }^{*}$ Penulis Penanggungjawab
} 
mengakibatkan berbagai permasalahn gizi dan berdampak pada prestasi belajar mereka. ${ }^{1}$

Hasil Riset Kesehatan Dasar (Riskesdas) Tahun 2013, menunjukkan bahwa secara nasional prevalensi anak pendek usia 5-12 tahun sebesar $30,7 \%$. Prevalensi kurus (menurut IMT/U) sebesar $11,2 \%$. Permasalahan gizi lebih yaitu $18,8 \%$ dan Provinsi Jawa tengah menjadi salah satu provinsi yang memiliki prevalensi sangat kurus yang tergolong tinggi secara nasional yaitu sebesar $5 \%{ }^{2}$

Permasalahan gizi pada anak SD biasanya diawali dengan kurangnya asupan energi dan protein di bawah kebutuhan minimal. ${ }^{3}$ Selain itu, prevalensi kurang makan buah dan sayur yang masih tergolong tinggi, aktivitas fisik yang masih tergolong rendah ${ }^{4}$ dan kebiasaan konsumsi makanan jajanan yang berpengaruh terhadap asupan energi dan proteinnya, ${ }^{5,7}$ serta memiliki kebiasaan memilih - milih makanan sehingga variasi makanan yang dikonsumsi menjadi kurang terpenuhi. ${ }^{6}$ Berbagai hasil penelitian menunjukkan bahwa konsumsi makanan jajanan anak SD masih belum memadai, tetapi anak SD seringkali menjadikan makanan jajanan sebagai sumber makanan utama $^{8}$ dan terbiasa makan makanan jajanan yang kurang sehat di sekolah daripada memakan makanan bekal dari rumah. ${ }^{9}$

Terjadinya permasalahan gizi dan sikap tentang gizi yang kurang baik pada anak SD salah satunya disebabkan oleh kurangnya pengetahuan gizi. ${ }^{10}$ Penelitian tentang pengetahuan gizi pada anak SD di Depok ${ }^{11}$ dan Banten menunjukkan skor hasil rata - rata pengetahuan gizi pada anak usia sekolah masih tergolong rendah. ${ }^{12}$

Pengetahuan adalah tingkatan terendah dalam perubahan sikap dan perilaku. ${ }^{10}$ Maka, untuk mencapai tahapan perubahan sikap sadar gizi dan mengurangi permasalahan gizi yang ada, perlunya dilakukan intervensi gizi yaitu dengan pemberian pendidikan gizi dengan materi pendidikan gizi seimbang untuk anak sekolah dasar. Dimana pendidikan gizi seimbang ini dapat mencakup kebiasaan makan, aktivitas fisik dan status gizi.

Pendidikan gizi yang diberikan pada anak usia sekolah dasar diupayakan diberikan melalui media yang menarik agar penyampaian materi dapat diterima dengan lebih mudah. Salah satu media yang menarik bagi anak - anak dan mampu meningkatkan pengetahuan secara signifikan yang kini telah banyak digunakan sebagai media edukasi adalah komik. ${ }^{13-18}$ Komik juga merupakan salah satu media cetak yang mudah digunakan, relatif murah, awet dan fleksible. ${ }^{18}$

Pedoman Gizi di Indonesia telah mengalami beberapa kali pergantian hingga banyak yang belum menyadari bahwa sebenarnya slogan Empat Sehat Lima Sempurna (4S5S) sudah tidak dipergunakan lagi dan berganti menjadi empat pilar yang digambarkan dengan tumpeng gizi seimbang yang belum tersosialisasi dengan baik ${ }^{19}$. Sebagian besar masyarakat, termasuk para guru SD tidak mengenal gizi seimbang. ${ }^{19}$

Sekolah dasar negeri Bendungan merupakan salah satu sekolah dasar negeri di Semarang yang pernah memiliki siswa dengan status gizi buruk pada tahun $2005 .{ }^{5}$ Selain itu, terdapat cukup banyak penjual makanan jajanan yang terlihat kurang terjamin keamanan dan kebersihannya berjualan di sekitar lingkungan sekolah dan umumnya ramai dikunjungi oleh siswa sekolah dasar tersebut.

\section{METODE}

Subyek yang diteliti adalah siswa kelas IV dan V SD yang memiliki kisaran usia $8-10$ tahun di SD Negeri Bendungan Semarang berstatus aktif dan bersedia menjadi subyek serta mengikuti seluruh rangkaian penelitian yang dipilih secara acak sederhana dan kemudian dibagi menjadi dua kelompok dengan jumlah sama rata.

Instrumen yang digunakan dalam penelitian ini adalah komik gizi seimbang yang dibuat oleh peneliti sebagai media pendidikan gizi dan kuesioner terstruktur untuk mengukur pengaruh pendidikan gizi yang diberikan melalui media komik terhadap pengetahuan dan sikap gizi seimbang pada subyek.

Penelitian ini berjenis quasi experimental dengan pre-post test two group design. Variabel bebas dalam penelitian ini adalah pendidikan gizi melalui komik gizi seimbang serta pendampingan. Variabel terikat dalam penelitian ini adalah pengetahuan dan sikap gizi seimbang.

Pemilihan subyek penelitian untuk pengelompokkan dan pemberian perlakuan menggunakan metode random sampling. Besar sampel yang diambil berdasarkan perhitungan jumlah sampel minimal menggunakan rumus uji hipotesis beda rerata pada dua kelompok dependen dengan antisipasi drop out sehingga didapatkan sampel sebanyak 33 orang per kelompok.

Penelitian ini dilaksanakan dalam 6 tahap yaitu pembuatan komik yang melalui tahap evaluasi dan revisi, pembuatan kuesioner yang selanjutnya melalui tahap pengujian validitas dan reliabilitas, pengambilan data pretest, pemberian pendidikan gizi, dan pengambilan data posttest. Pembuatan komik dilakukan oleh peneliti melalui tahapan awal berupa sketsa manual kemudian tahap evaluasi dan revisi. Setelah sketsa dianggap telah sesuai, dilakukan editing gambar untuk pewarnaan dan 
design layout dengan software Adobe photoshop Element 6.0. Kemudian komik yang telah diedit, dicetak secara sederhana dengan printer untuk dilakukan evaluasi dan revisi kembali sebelum diperbanyak. Evaluasi dilakukan berdasarkan pada hasil angket tentang komik gizi seimbang tersebut pada 20 siswa kelas IV dan V di SDN 01 Petompon Semarang. Setelah komik dinyatakan layak dan cocok dari sisi gambar, warna, tulisan, bahasa serta kontennya, maka komik dicetak. Komik dibuat berdasarkan pada buku pedoman gizi seimbang untuk anak sekolah dasar ${ }^{19}$ dan buku gizi seimbang panduan peserta didik, ${ }^{20}$ dengan ilustrasi dari peneliti, berwarna, menggunakan bahasa yang sederhana dan jelas.

Pre-test dilakukan menggunakan kuesioner berjumlah 50 pertanyaan pilihan berganda yang terdiri dari 25 pertanyaan berbentuk pilihan benar atau salah untuk kuesioner pengetahuan dan 25 pertanyaan berbentuk pilihan dengan skala setuju atau tidak setuju untuk kuesioner sikap gizi seimbang. Kuesioner yang digunakan terlebih dahulu telah dilakukan uji validitas pada 20 siswa kelas IV dan V di SDN 01 Petompon Semarang dan dinyatakan valid dan reliabel sebagai instrumen penelitian. Lokasi pengujian kuesioner dipilih atas dasar kesamaan karakteristik dengan SDN Bendungan Semarang. Pre-test ini dilakukan sebagai gambaran untuk mengetahui pengetahuan dan sikap gizi awal subyek sebelum dilakukan intervensi.

Intervensi pendidikan gizi melalui pemberian komik pada kelompok 1 dan pemberian komik serta pendampingan pada kelompok 2 dilakukan beberapa hari setelah pelaksanaan pre-test. Komik diberikan dengan waktu \pm 30 menit untuk subyek membacanya sendiri, setelah itu pada kelompok 2 diberikan pendampingan dan penjelasan secara lisan selama 4 kali yaitu 1x/minggu selama sebulan oleh peneliti.

Post-test dilakukan sehari setelah pemberian intervensi terakhir. Pelaksanaan post test dilakukan untuk mengetahui pengetahuan dan sikap gizi seimbang pada subyek setelah dilakukan intervensi pendidikan gizi seimbang melalui komik dan pendampingan.

Data yang dikumpulkan berupa skor pengetahuan dan sikap tentang gizi seimbang yang didapatkan melalui kuesioner diuji normalitasnya dengan uji Kolmogorov Smirnov. Perbedaan skor pengetahuan dan sikap gizi antara sebelum dan setelah intervensi diuji dengan uji Wilcoxon dan uji paired $t$-test. Perbedaan pengaruh pendidikan gizi terhadap pengetahuan dan sikap antara kelompok yang hanya diberikan komik dengan kelompok yang diberikan komik serta pendampingan menggunakan uji Mann-Whitney.

\section{HASIL PENELITIAN \\ Karakteristik Subyek}

Subyek dalam penelitian ini adalah siswa SD kelas IV dan V. Karakteristik median usia subyek yaitu 9 tahun, dengan usia terendah yaitu 8 tahun dan yang paling tinggi yaitu usia 10 tahun. Hasil uji hubungan menunjukkan tidak ada hubungan usia dengan pengetahuan dan sikap dalam penelitian ini $(p>0,05)$.

Tabel 1. Distribusi Jenis Kelamin Subyek pada kedua kelompok

\begin{tabular}{ccccccc}
\hline \multirow{2}{*}{ Jenis Kelamin } & \multicolumn{2}{c}{ Kelompok 1 $(\mathbf{n = 3 3})$} & \multicolumn{1}{c}{ Kelompokn 2 $(\mathbf{n}=\mathbf{3 3})$} & \multicolumn{2}{c}{ Total } \\
\cline { 2 - 7 } & $\mathbf{n}$ & $\mathbf{\%}$ & $\mathbf{n}$ & $\mathbf{\%}$ & $\mathbf{n}$ & $\mathbf{\%}$ \\
\hline Laki - Laki & 17 & 51,5 & 20 & 60 & 37 & 56 \\
Perempuan & 16 & 48,5 & 13 & 40 & 29 & 44 \\
\hline Total & $\mathbf{3 3}$ & $\mathbf{1 0 0}$ & $\mathbf{3 3}$ & $\mathbf{1 0 0}$ & $\mathbf{6 6}$ & $\mathbf{1 0 0}$ \\
\hline
\end{tabular}

Tabel 1 menunjukkan bahwa 37 (56\%) subyek berjenis kelamin laki - laki. Dimana jika dilihat pada masing - masing kelompok, persentase subyek laki - laki pada kelompok perlakuan 1 sebesar 51,5\% dan pada kelompok perlakuan 2 sebesar $60 \%$.

Tabel 2. Pendidikan Ibu pada kedua kelompok

\begin{tabular}{ccccc}
\hline \multirow{2}{*}{ Tingkat Pendidikan Ibu } & \multicolumn{2}{c}{ Kelompok 1 $(\mathbf{n = 3 3})$} & \multicolumn{2}{c}{ Kelompok 2 $(\mathbf{n}=\mathbf{3 3})$} \\
\cline { 2 - 5 } & $\mathbf{n}$ & $\mathbf{\%}$ & $\mathbf{n}$ & $\mathbf{\%}$ \\
\hline SD (6 tahun) & 4 & 12,1 & 3 & 9,1 \\
SMP (9 tahun) & 5 & 15,2 & 8 & 24,2 \\
SMA (12 tahun) & 17 & 51,5 & 15 & 45,5 \\
Perguruan Tinggi & 7 & 21,2 & 7 & 21,2 \\
\hline Total & $\mathbf{3 3}$ & $\mathbf{1 0 0}$ & $\mathbf{3 3}$ & $\mathbf{1 0 0}$ \\
\hline
\end{tabular}


Tabel 2 menunjukkan bahwa tingkat pendidikan ibu subyek pada kedua kelompok paling banyak yaitu setingkat SMA atau dengan lama pendidikan 12 tahun. Hasil uji hubungan menunjukkan tidak ada hubungan tingkat pendidikan ibu dengan pengetahuan dan sikap dalam penelitian ini $(\mathrm{p}>0,05)$.

Perbedaan Pengetahuan Gizi Seimbang Sebelum dan Setelah Pemberian Pendidikan Gizi Seimbang pada Kedua Kelompok

Tabel 3. Pengetahuan subyek sebelum dan setelah pemberian pendidikan gizi seimbang pada kedua kelompok

\begin{tabular}{lccc}
\hline \multicolumn{1}{c}{ Pengetahuan } & Pretest & Posttest & $p$ \\
\hline $\begin{array}{c}\text { Kelompok 1 } \\
\begin{array}{c}\text { Median ( Minimum - Maksimum) } \\
\text { Kelompok 2 } \\
\text { Mean } \pm \text { SD }\end{array}\end{array}$ & $56(16-76)$ & $72(36-92)$ & $0,000^{\mathrm{a}}$ \\
\hline
\end{tabular}

Keterangan: Wilcoxon $\mathrm{b}=$ paired $t$-test

Tabel 3 menujukkan hasil bahwa terdapat perbedaan pengetahuan tentang gizi seimbang antara sebelum dan setelah pemberian pendidikan gizi melalui komik pada kedua kelompok perlakuan $(\mathrm{p}<0,05)$. Hasil uji beda menunjukkan tidak ada perbedaan skor pengetahuan pre-test pada kedua kelompok $\quad(p=0,356 ; \quad p>0,05)$ Distribusi peningkatan pendidikan gizi seimbang pada kedua kelompok dapat terlihat pada Tabel 4.

Tabel 4. Distribusi peningkatan pendidikan gizi seimbang pada kedua kelompok

\begin{tabular}{lccc}
\hline \multirow{2}{*}{ Variabel Pengetahuan } & \multicolumn{2}{c}{ Jawaban Benar (\%) } & \multirow{2}{*}{ Rerata Peningkatan (\%) } \\
\cline { 2 - 3 } & Pretest & Posttest & \\
\hline Tumpeng Gizi Seimbang & 40,3 & 60,8 & 20,5 \\
Pilar I (Makan makanan beranekaragam) & 51,5 & 80,3 & 28,8 \\
Pilar II (Pola hidup bersih dan sehat) & 87,2 & 87,7 & 0,5 \\
Pilar III (Aktivitas Fisik) & 69,3 & 84 & 14,7 \\
Pilar IV (Memantau dan menjaga BBI) & 51,2 & 69,6 & 18,4 \\
\hline
\end{tabular}

Tabel 4 menunjukkan secara umum seluruh variabel pengetahuan mengalami peningkatan yang cukup signifikan kecuali pada variabel Pilar II (Pola Hidup Bersih) yang hanya mengalami peningkatan

\section{Sikap Gizi Seimbang Sebelum dan Setelah Pendidikan Gizi Seimbang pada Kedua Kelompok} sebesar $0,5 \%$.

Tabel 5. Sikap subyek sebelum dan setelah pemberian pendidikan gizi seimbang pada kedua kelompok

\begin{tabular}{lccc}
\hline \multirow{2}{*}{ Sikap } & \multicolumn{2}{c}{$\begin{array}{c}\text { Median } \\
\text { (Minimum-Maksimum) }\end{array}$} & $\boldsymbol{p}$ \\
\cline { 2 - 3 } & Pretest & Posttest & $0,000^{\mathrm{a}}$ \\
Kelompok 1 & $64(8-88)$ & $88(24-100)$ & $0,000^{\mathrm{a}}$ \\
Kelompok 2 & $60(44-84)$ & $84(60-100)$ & \\
\hline
\end{tabular}

Keterangan: $\mathrm{a}=$ Wilcoxon

Tabel 5 menujukkan bahwa terdapat perbedaan sikap tentang gizi seimbang antara sebelum dan setelah pemberian pendidikan gizi melalui komik pada kedua kelompok perlakuan $(\mathrm{p}<0,05)$. Hasil uji beda menunjukkan tidak ada perbedaan skor sikap pre-test pada kedua kelompok $(\mathrm{p}=0,606 ; \mathrm{p}>0,05)$.Distribusi peningkatan sikap gizi seimbang pada kedua kelompok dapat terlihat pada Tabel 6. 
Tabel 6. Distribusi peningkatan sikap gizi seimbang pada kedua kelompok

\begin{tabular}{lccc}
\hline \multicolumn{1}{c}{ Variabel Sikap } & \multicolumn{2}{c}{ Jawaban Benar $(\%)$} & \multirow{2}{*}{ Rerata Peningkatan (\%) } \\
\cline { 2 - 3 } & Pretest & Postest & \\
\cline { 1 - 2 } Pilar I (Makan makanan beranekaragam) & 62,3 & 79,4 & 17,1 \\
Pilar II (Pola hidup bersih dan sehat) & 83,5 & 91 & 7,5 \\
Pilar III (Aktivitas Fisik) & 60,8 & 83,4 & 22,6 \\
Pilar IV (Memantau dan menjaga BBI) & 32 & 75 & 43 \\
\hline
\end{tabular}

Tabel 6 menunjukkan bahwa secara umum semua variabel sikap mengalami peningkatan. Peningkatan sikap yang paling signifikan terjadi pada Pilar IV (Memantau dan menjaga BBI) yang meningkat sebesar 43\%. Variabel sikap yang mengalami peningkatan paling sedikit adalah pada Pilar II (Pola hidup bersih dan sehat) yang hanya mengalami peningkatan sebesar 7,5\% .

\section{Perbedaan Peningkatan Pengetahuan dan Sikap antar Kelompok Perlakuan}

Untuk melihat efektifitas pengaruh pendidikan gizi maka dapat dilihat dari delta peningkatan pengetahuan dan sikap pada kedua kelompok perlakuan yang dapat dilihat pada Tabel 7.

Tabel 7. Perbedaan Peningkatan Skor Pengetahuan dan Sikap antar Kelompok Perlakuan

\begin{tabular}{lcccc}
\hline \multicolumn{1}{c}{ Variabel } & \multicolumn{3}{c}{ Perubahan $(\boldsymbol{\Delta})$} & \multirow{2}{*}{$\boldsymbol{p}$} \\
\cline { 2 - 4 } Pengetahuan & Median & Min & Max & \\
$\quad$ Kelompok 1 & 8 & 0 & 60 & 0,022 \\
Kelompok 2 & 16 & 0 & 56 & \\
\hline Sikap & & & & \\
$\quad$ Kelompok 1 & 20 & 0 & 52 & 0,728 \\
Kelompok 2 & 20 & 0 & 40 & \\
\hline
\end{tabular}

Tabel 7 menujukkan bahwa adanya perbedaan yang bermakna pada peningkatan pengetahuan gizi seimbang antara kelompok perlakuan 1 dan $2(\mathrm{p}<0,05)$. Sedangkan pada peningkatan sikap tentang gizi seimbang antar kedua kelompok tidak menujukkan adanya perbedaan yang bermakna $(p>0,05)$.

\section{PEMBAHASAN}

Hasil penelitian ini menunjukkan bahwa ada pengaruh pendidikan gizi melalui komik gizi seimbang terhadap pengetahuan tentang gizi seimbang pada kedua kelompok perlakuan. Peningkatan pengetahuan gizi pada hasil penelitian ini sesuai dengan penelitian yang telah dilakukan sebelumnya pada anak SD di Bogor pada tahun 2010 yang diberikan buku cerita bergambar sebanyak 1 kali selama satu bulan yang meningkatkan pengetahuan gizi dari sebelumnya tergolong kurang menjadi baik. ${ }^{13}$ Penelitian pada anak SD di Tangerang pada tahun 2012 yang diberikan komik gizi sebanyak 1 kali juga menunjukkan peningkatan pengetahuan gizi dari sebelumnya tergolong kurang menjadi cukup. ${ }^{15}$

Peningkatan pengetahuan gizi seimbang bila dibandingkan antar kelompok perlakuan 1 dan 2 menujukkan adanya perbedaan yang bermakna.
Hasil ini menujukkan bahwa peningkatan pengetahuan gizi seimbang pada kelompok perlakuan yang diberikan komik dan pendampingan memiliki peningkatan yang lebih besar dibandingkan dengan peningkatan pengetahuan gizi pada kelompok perlakuan yang hanya diberikan komik. Adanya perbedaan peningkatan pengetahuan pada kelompok perlakuan 1 dan 2 dikarenakan waktu pendidikan gizi yang diberikan pada kelompok 2 lebih banyak dan intensif daripada kelompok 1 sehingga, kelompok 2 lebih dapat menyerap dan mengingat materi dengan baik yang mengakibatkan peningkatan pengetahuan pada kelompok 2 lebih besar daripada kelompok 1 . Pendidikan melalui indera pendengaran akan menghasilkan keberhasilan $15 \%$ sedangkan pendidikan melalui indera pendengaran dan penglihatan akan menghasilkan keberhasilan 35$55 \%{ }^{23} \mathrm{Hal}$ ini menujukkan bahwa efektivitas komik sebagai media pendidikan akan lebih baik apabila dipandu dengan pendampingan atau penjelasan lisan. ${ }^{30}$

Secara umum pengetahuan gizi seimbang yang terbagi menjadi 4 pilar ini mengalami peningkatan pada keseluruhan pilarnya kecuali pada pilar kedua yang hanya mengalami sedikit peningkatan. Peningkatan yang tidak signifikan 
pada pilar kedua yaitu tentang pola hidup bersih dapat disebabkan secara umum materi tersebut telah sering diberikan sehingga pengetahuan yang dimiliki sebagian besar subyek tentang hal tersebut sudah termasuk dalam kategori baik. Sementara pengetahuan tentang tumpeng gizi seimbang, dan ked pilar lainnya masih tergolong asing bagi subyek, sehingga pendidikan gizi yang diberikan memberikan pengaruh terhadap peningkatan pengetahuan yang lebih besar.

Selain pengetahuan, hasil penelitian ini juga menujukkan bahwa adanya peningkatan sikap tentang gizi seimbang pada kedua kelompok perlakuan setelah pemberian pendidikan gizi melalui komik gizi seimbang. Peningkatan sikap gizi sebagai hasil dalam penelitian ini bertentangan dengan hasil penelitian pada siswa SD di Semarang pada tahun 2009 yang diberikan komik makanan jajanan yang tidak memberikan efek terhadap peningkatan sikap dalam memilih makanan jajanan. ${ }^{8}$ Komik Makanan Jajanan dalam penelitian tersebut tidak memberikan efek terhadap perubahan sikap anak SD, dikarenakan konsep keanekaragaman makanan jajanan yang disajikan melalui media komik masih sulit dicerna oleh anak. ${ }^{8}$

Peningkatan sikap gizi seimbang apabila dibandingkan antar kelompok, menujukkan hasil bahwa tidak ada perbedaan yang bermakna. Pada kedua kelompok tersebut terjadi peningkatan yang relatif sama, meskipun kelompok perlakuan yang hanya diberikan komik lebih sedikit menerima pendidikan gizi dibandingkan kelompok perlakuan yang diberikan komik dan pendampingan intensif. Hal ini dapat dikarenakan sikap tidak selalu dipengaruhi oleh pengetahuan. Seseorang dapat memiliki sikap yang baik meskipun tidak mengetahui ilmu, alasan atau latar belakang dari suatu sikap yang dipilih tersebut secara baik dan benar.

Berdasarkan peningkatan sikap pada tiap tiap pilar gizi seimbang, secara umum keseluruhan variabel sikap mengalami peningkatan yang cukup signifikan. Peningkatan yang paling sedikit terjadi dibandingkan ketiga pilar lainnya yaitu pada pilar kedua tentang pola hidup bersih. Hal ini dapat disebabkan waktu pendidikan yang kurang cukup dan kurangnya pengendalian terhadap faktor faktor lain yang dapat mempengaruhi terjadinya peningkatan sikap tersebut.

Pengetahuan dan sikap dipengaruhi oleh berbagai macam faktor salah satunya adalah pendidikan atau edukasi. ${ }^{21}$ Pendidikan merupakan salah satu alat untuk menghasilkan perubahan pada diri manusia, karena melalui pendidikan manusia akan dapat mengetahui segala sesuatu yang tidak atau belum diketahui sebelumnya. ${ }^{21}$ Pendidikan diartikan sebagai sebuah proses dengan metodemetode tertentu sehingga orang memperoleh pengetahuan, pemahaman dan cara bertingkah laku yang sesuai dengan kebutuhan. ${ }^{22}$ Pendidikan gizi diperlukan untuk meningkatkan pengetahuan gizi siswa, membentuk sikap positif terhadap makanan bergizi dalam rangka membentuk kebiasaan makan yang baik. ${ }^{21}$

Alasan utama yang menyebabkan terjadinya peningkatan pengetahuan dan sikap tentang gizi seimbang dalam penelitian ini adalah pendidikan melalui media pendidikan yang digunakan dan cara penyampaian materi pendidikan. Media pendidikan berfungsi untuk mengerahkan indera sebanyak mungkin kepada suatu objek sehingga mempermudah persepsi. Media pendidikan membuat seseorang dapat lebih mengerti informasi atau materi yang dianggap rumit menjadi lebih mudah. ${ }^{25}$ Dalam hal ini, media pendidikan gizi yang digunakan adalah komik yang bertemakan gizi seimbang.

Komik memiliki karakteristik yang memenuhi syarat- syarat pemilihan media pendidikan yang baik bagi siswa, yaitu menarik minat dan perhatian siswa (attention), sesuai dengan tujuan pembelajaran dan kebutuhan serta kondisi siswa (relevance), mampu menimbulkan rasa percaya pada siswa bahwa mereka mampu dalam menyerap informasi yang diberikan (confidence), dan tidak hanya memberikan pengetahuan kepada siswa tetapi juga mampu menimbulkan rasa senang (hiburan). ${ }^{26}$ Sebagai media pendidikan yang telah banyak digunakan beberapa kelebihan komik, yaitu mampu menambah perbendaharaan kata pembacanya, mempermudah merumuskan hal - hal abstrak, dan mengembangkan minat baca. ${ }^{27}$ Sementara itu, komik sebagai media grafis memiliki keunggulan, yaitu mampu menarik perhatian, memperjelas penyampaian ide, dan mengilustrasikan informasi sehingga mudah diingat. ${ }^{28}$

Media visual yang ditambahkan dalam pesan verbal dapat meningkatkan motivasi anak untuk menerima pesan dan mengingatnya dengan lebih baik. ${ }^{29}$ Rangsangan visual yang diberikan kepada seseorang dapat menyumbangkan daya serap terhadap materi sebesar $30 \%$, dibandingkan dengan membaca teks yang hanya menyumbangkan $10 \% .{ }^{24}$ Dengan demikian materi gizi seimbang yang disampaikan melalui komik dapat diterima dengan lebih baik dan mudah oleh subyek.

Selain media, terjadinya peningkatan pengetahuan dan sikap juga dipengaruhi oleh kemampuan komunikasi dan penyampaian materi 
yang baik, khususnya pada kelompok perlakuan 2 yang membutuhkan penjelasan lisan dalam rangkaian penelitian ini. Komunikasi dalam proses pendidikan merupakan persoalan yang sangat penting. Komunikasi adalah transfer ide atau informasi dari satu orang ke orang lain. Pembicara yang menguasai materi yang disampaikan, dapat menaikkan perhatian penerima, berbicara jelas dan dapat memahami siapa yang dihadapi akan mempermudah proses penyampaian pesan dan informasi. ${ }^{24}$

\section{SIMPULAN}

Pendidikan gizi melalui komik gizi seimbang meningkatkan pengetahuan dan sikap tentang gizi seimbang secara bermakna. Terdapat perbedaan yang bermakna pada peningkatan pengetahuan gizi seimbang antara kelompok perlakuan yang hanya diberi komik dengan kelompok perlakuan yang diberikan komik dan pendampingan. Tidak ada perbedaan pada peningkatan sikap gizi seimbang antara kelompok perlakuan yang hanya diberi komik dengan kelompok perlakuan yang diberikan komik dan pendampingan.

\section{SARAN}

Perlunya penelitian lebih lanjut mengenai pemberian media komik sebagai media pendidikan gizi terhadap pengetahuan, sikap dengan pengemasan media yang lebih menarik dan waktu yang lebih panjang serta melibatkan peran serta guru dan orangtua.

\section{DAFTAR PUSTAKA}

1. Setiawan Yahmin dan Dharmawan A.C. Masalah Gizi pada anak sekolah dasar. Diakses tanggal 16 April

2014. http://www.lkc.or.id/2012/09/14/masalah-gizipada-anak-sekolah-dasar/ 2012

2. Departemen Kesehatan RI. Laporan Hasil Riset Kesehatan Dasar (RISKESDAS). 2013

3. Departemen Kesehatan RI. Laporan Hasil Riset Kesehatan Dasar (RISKESDAS). 2010

4. Departemen Kesehatan RI. Laporan Hasil Riset Kesehatan Dasar (RISKESDAS). 2007

5. Sulistyanto, Joko. Kontribusi makanan jajanan terhadap tingkat kecukupan energi dan protein serta status gizi dalam kaitannya dengan prestasi belajar anak sekolah dasar. studi di SD H. Isriati dan SDN Bendungan Semarang (Skripsi). Universitas Diponegoro. 2005.

6. Supardin1, Nurhaema, Veni. H dan Saifuddin. S. Hubungan asupan zat gizi dengan status hemoglobin pada anak sekolah dasar di wilayah pesisir kota makassar tahun 2013.(Artikel Penelitian) Universitas Hassanudin; 2013.
7. Sulistyanto, Joko. Kontribusi makanan jajanan terhadap tingkat kecukupan energi dan protein serta status gizi dalam kaitannya dengan prestasi belajar anak sekolah dasar. studi di SD H. Isriati dan SDN Bendungan Semarang (Skripsi). Universitas Diponegoro. 2005.

8. Widajanti, Laksmi, Chriswardani Suryawati dan Anung Sugihantono. Pengaruh komik makanan jajanan sehat dan bergizi untuk meningkatkan pengetahuan dan sikap anak sekolah dasar. The Indonesian Journal of Public Health, Vol. 6, No. 1, Juli 2009: 19-23

9. Ariandani Aprilia, Bondika. Faktor yang berhubungan dengan pemilihan jajan pada anak sekolah dasar (skripsi). Universitas Diponegoro. 2011.

10. Notoatmodjo, Soekidjo. 2003. Ilmu Kesehatan Masyarakat (prinsip-prinsip dasar). Rineka Cipta: Jakarta

11. Achadi, E, dkk. 2010. Pemberdayaan masyarakat melalui peningkatan pengetahuan, sikap dan prilaku tentang gizi seimbang pada anak sekolah dasar, di kota depok, propinsi jawa barat : suatu kegiatan multisenter. Depok: Direktorat Riset dan Pengabdian kepada Masyarakat (UI) dan Lembaga Penelitian dan Pengabdian kepada Masyarakat (IPB).

12. Atmaja, A. T. Pengetahuan gizi seimbang daerah perkotaan dan pedesaan pada pendidikan gizi anak sekolah dasar kebupaten serang provinsi banten tahun 2010 (data sekunder) (skripsi). Universitas Indonesia; 2010.

13. Arimurti, Ditta Irma. Pengaruh pemberian komik pendidikan gizi seimbang terhadap pengetahuan gizi siswa kelas V SDN sukasari 4 kota tangerang (skripsi). Universitas Indonesia. 2012.

14. Ulfa, M. Efektifitas pembelajaran dengan media panggung boneka dan komik transparasi dalam membentuk sikap moral siswa dan sekolah dasar. Jurnal penelitian dasar, 2014, 5 (1) 11-21. http://www.fip.unesa.ac.id.

15. Ikada, Delina Citrayani. Tingkat penerimaan buku cerita bergambar sebagai media pendidikan gizi dan pengaruhnya terhadap pengetehuan gizi anak sekolah dasar (skripsi). Institut Pertanian Bogor. 2010.

16. Netty, Roseswinda, Sari,J., Ichwani,I. Pemberdayaan media komik ilmu pengetahuan alam (kolam) untuk meningkatkan pemahamam konsep IPA (PKMP) (skripsi). Universitas Negeri Padang. 2010 http://www.directory.umm.ac.id.

17. Avrilliyanti, Herlina dkk. 2013. Penerapan media komik untuk pembelajaran fisika model kooperatif dengan metode diskusi pada siswa SMP Negeri 5 Surakarta kelas VII Tahun ajaran 2011/2012 materi Gerak. Program Studi pendidikan Fisika UNS. Jurnal Pendidikan Fisika (2013) Vol.1 No.1 h. 156.

18. Gafur, A. Pengembangan media pembelajaran. Universitas Negeri Yogyakarta; 2010. http://www.staf.uny.ac.id. 
19. Yayasan Institut Danone Indonesia. Pedoman Gizi Seimbang Untuk Anak Usia Sekolah Dasar. 2013. Jakarta : Citra Kreasindo.

20. PGK dan PUSKA FKM Universitas Indonesia. 2011. Gizi seimbang buku panduan peserta didik.

21. Khomsan, A. 2000. Teknik pengukuran pengetahuan gizi. Bogor : Intitut Pertanian Bogor.

22. Backes L. Understanding children's books genres. http://www.right-writing.com/genres.html. 2007.

23. Syah,Muhibbin.2010.Psikologi Pendidikan Dengan Pendekatan Baru.Bandung : Remaja Rosdakarya

24. Suhardjo. 2003. Berbagai cara pendidikan gizi. Jakarta: Bumi Aksara

25. Fitriani, Sinta. 2011. Promosi Kesehatan. Yogyakarta: Garaja Ilmu.

26. Supardi. Optimalisasi penggunaan dan pengembangan media pembelajaran untuk prefesionalisasi guru. http://www.staff.uny.ac.id. 2009

27. Lestari, S. Putri, S dan Yuniarti. Media Komik. Bandung: Fakultas Ilmu Pendidikan. Universitas Indonesia. http://www.file.upi.edu. 2009.

28. Indriana, D. (2011). Ragam alat bantu media pengajaran. Yogyakarta : DIVA press.

29. Contento IR. 2007. Nutrition Education: Linking Research, Theory, and Practice. Sudbury: Jones and Bartlett Publishers.

30. Masithoh, Siti. Pengaruh pemberian komik terhadap hasil belajar kognitif siswa pada konsep sistem pencernaan makanan. (penelitian Quasi Experiement di SMAN 5 Tangerang Selatan) (Skripsi). Universitas Islam Negeri Syarif Hidyatullah Jakarta; 2012. 